\title{
Stability Control of Staged Filling Construction on Soft Subsoil Using Hyperbolic Settlement Prediction Method: A Case Study of a Tidal Flat in China
}

\author{
Fei Yu $\left(\mathbb{D},{ }^{1}\right.$ Shichang Li, ${ }^{1,2}$ Zhangjun Dai ${ }^{1},{ }^{1}$ Jian Li $\left(\mathbb{D},{ }^{1}\right.$ and Shanxiong Chen ${ }^{1}$ \\ ${ }^{1}$ State Key Laboratory of Geomechanics and Geotechnical Engineering, Institute of Rock and Soil Mechanics, \\ Chinese Academy of Sciences, Wuhan 430071, China \\ ${ }^{2}$ University of Chinese Academy of Sciences, Beijing 100049, China
}

Correspondence should be addressed to Fei Yu; fyu@whrsm.ac.cn

Received 11 May 2020; Revised 17 June 2020; Accepted 2 July 2020; Published 8 August 2020

Academic Editor: Qiang Tang

Copyright (C) 2020 Fei Yu et al. This is an open access article distributed under the Creative Commons Attribution License, which permits unrestricted use, distribution, and reproduction in any medium, provided the original work is properly cited.

An improved method, which combines in situ measured settlement data, hyperbolic method, and deep lateral displacement rate, is presented in this study to predict the consolidation and stability of the ground, which can be used in conducting staged filling construction on soft subsoil. A case history of a highway embankment construction in a tidal flat with thick mucky clay is studied in $\mathrm{Xia} \mathrm{Pu}$, China. Preloading with the prefabricated vertical drain method is adopted to accelerate the consolidation of a subgrade. The field behavior of soft ground under filling load is observed through in situ monitoring sensors in four typical sections. The final ground settlement in each stage is determined using the field monitoring data based on the hyperbolic settlement prediction method. For each stage of graded filling load, the ground settlement with a strain consolidation degree of 95\% is defined as the standard settlement, and the corresponding settlement time is set as the standard settlement time. The preloading period is estimated according to the standard settlement time. The deep lateral displacement rate of the ground is monitored to control the stability of the foundation and recommended to guide the embankment construction. Results indicate that the presented method can predict the preloading time of graded filling, reduce the frequency of observation, and ensure the consolidation and stability of the ground.

\section{Introduction}

A large number of roads have been recently built on prefabricated vertical drain- (PVD-) improved soft soil in tidal flats combined with staged preloading construction to accelerate the consolidation of soil and shorten the construction period [1-4]. PVDs have increased the vertical hydraulic conductivity of soft subsoil by approximately 30 times compared with the original nontreated subsoil using finite element method [5]. The key point of the long-term behavior of the embankment, which is routinely subjected to design analysis, is the settlement [6]. The methods used in predicting ground settlement can be categorized into three main types: consolidation theory, numerical calculation, and curve fitting. A number of recent papers on consolidation theory has been published [7-9]. Consolidation theory is difficult to apply in practical engineering considering smear and well resistance. The numerical methods are time consuming, and the parameters are difficult to determine economically and apply in practical engineering [10].

However, predictions of the induced consolidation settlement are frequently unsuccessful whether simplified theoretical solutions or advanced numerical approaches are used, especially in the case of thick or heterogeneous soil deposit [11]. Thus, developing observational methods, which include curve fitting and can be used as a basis in estimating the settlement once sufficient data are recorded, is important. Filippo et al. [12] compared in situ measurements and theoretical predictions of ground settlements induced by preloading and vertical drains on a heterogeneous soil deposit. Chen et al. [13] analyzed the performance of four classical curve fitting methods using field data, including the hyperbola, expanded hyperbola, three-point fitting, and Asaoka methods, and proposed a novel approach to estimate 
ground settlement. Sinha et al. [14] concluded that the inflection point method can be potentially used in field applications; they also provided an alternate method to estimate the total settlement in field applications using PVDs and surcharge and determine the appropriate required waiting period for staged loading. Haeri and Sasar [15] proposed a method that can improve the final settlement predicted by the Asaoka method, considering the effects of creep. Wang et al. [16] analyzed a large number of test data using mathematical methods, such as hyperbolic fitting method and logarithmic curve forecasting method; the obtained results can provide the ground treatment experience for geotechnical engineers. The hyperbolic method, which can indicate the influence of the secondary consolidation of the soil to a certain extent, can predict the final settlement. This approach is widely used in practical engineering, especially in coastal highway construction [17-20]. Li [21] proposed a concept called "potential settlement" and a simplified method based on in situ data using hyperbolic settlement prediction method. Hyperbolic methods have revealed that the magnitude of the final settlement increases and the degree of consolidation subsequently decreases as the period of assessment used in the prediction is prolonged [22].

Staged construction is a typical procedure for embankments on soft ground. With a certain period of consolidation at each staged construction, the safety factor of the embankment can be generally raised, and the postconstruction settlement may be reduced. The settlementtime curve during a staged construction may be more complicated than it is with instantaneous loading.

For the subgrade settlement under a staged load, the settlement-time curve has obvious "step phenomenon" [23-26]. Moreover, the above methods are usually used to analyze the settlement observation data under the dead loading phase, which cannot promptly provide guidance during the staged construction. Yang [27] adopted a new method for the settlement prediction of stage-constructed embankment on soft ground based on traditional exponent fitting method. Combined FEM analysis and field measured results indicate that the undrained shear strength increased twice, and the staged construction could retain the high stability of the embankment [28]. Leroueil et al. [29] revealed the effective stress path and analyzed the relationship between vertical settlement and deep lateral displacement during a staged construction. Yang et al. [30] presented a new model for the settlement prediction of staged constructed embankment on soft ground based on the traditional hyperbolic method; the system deformation characteristics reflected by the settlement of the embankment under the preload were used to predict the settlement development on the latter period of preload-bearing compression. Liu and Jing [31] presented a staged observational method for the settlement prediction of embankment on soft ground with staged construction; they determined that the immediate settlement contributes to the shift distance of the parallel lines during staged construction. Indraratna and Redana [23] proposed the settlement prediction for staged filling construction method, which can predict both the final and staged settlements during the filling steps in a PVD-improved soft ground.
Comprehensively understanding the consolidation of the ground on embankment construction using only monitoring settlement data is challenging. However, the deep lateral displacement rate is also an important factor to evaluate the stability of the subgrade. Subgrade deformation is almost a consolidation settlement on embankment construction. However, the deep lateral displacement of the ground obviously increases when the imposed load reaches a certain extent, and the lateral extrusion of the soft soil is serious, which contributes to ground damage. Therefore, the stability of the ground can be accurately and objectively evaluated by conducting a comprehensive analysis of field observations based on the field settlement prediction combined with the analysis of the deep lateral displacement trend of the slope foot on embankment.

An improved method combined with in situ measured settlement data, hyperbolic method, and deep lateral displacement rate is presented in this study. This method can be used to predict the consolidation and the stability of the ground, which can be used to conduct the staged filling construction on soft subsoil. The field behavior of the soft ground under filling load is observed by monitoring the surface settlement, Earth pressure, deep lateral displacement of the subsoil at the embankment side slope foot, pore pressure variation, and layered settlement at different depths in four typical sections. The final ground settlement in each stage is determined by the field monitoring data based on the hyperbolic settlement prediction method. The ground settlement with a strain consolidation degree of $95 \%$ is defined as the standard settlement, and the corresponding settlement time is set as the standard settlement time. The preloading period can be estimated according to the standard settlement time under each stage. Ground stability and the trend of the settlement consolidation are obtained and combined with the deep lateral displacement rate at the slope foot on the embankment under each stage, which can be used to guide the embankment construction. The settlement data measured from a field improved with PVDs and preloading consolidation in a tidal flat of $\mathrm{Xia} \mathrm{Pu}$, China, is performed to validate the proposed method. The ground stability is analyzed under staged filling construction on soft subsoil by controlling the predicted preloading period with the proposed method.

\section{Hyperbolic Settlement Prediction Method}

The hyperbolic method [32] assumes that the measured settlement-time curve of the embankment is changed by the hyperbolic curve under the preloading phase. The settlement fitting equation is

$$
S_{t}=S_{0}+\frac{t-t_{0}}{\alpha+\beta\left(t-t_{0}\right)},
$$

where $S_{t}$ is the settlement at $t, t_{0}$ is the zero point of the fitting curve, $S_{0}$ is the measured settlement at $t_{0}$, and $\alpha$ and $\beta$ are undetermined coefficients.

To determine the calculation parameters, equation (1) is rewritten as 


$$
\frac{t-t_{0}}{S_{t}-S_{0}}=\alpha+\beta\left(t-t_{0}\right) .
$$

According to the measured settlement data, $\alpha$ and $\beta$ can be determined from the intercept and slope of the straight line that fits the relationship between $\left(t-t_{0}\right) /\left(S_{t}-S_{0}\right)$ and $\left(t-t_{0}\right)$, respectively. The final settlement is obtained as follows:

$$
S_{f}=S_{0}+\frac{1}{\beta} \text {. }
$$

\section{Steps in Conducting the Staged Construction}

According to the measured settlement data, the preloading period of each stage is estimated, which can effectively control the stability of the embankment filling construction on the soft ground. The basic steps are as follows:

(1) The settlement data, $\left(S_{0 i}, t_{0 i}\right) \cdots\left(S_{T i}, t_{T i}\right)$, are tested for settlement prediction in the preloading period $T$ specified from the loading stop time in each stage of the filling load.

(2) The final settlement $S_{f i}$ of the ground under each staged filling load is calculated based on the hyperbolic method.

(3) The required consolidation of preloading should not be less than $90 \%$ [30]. The ground settlement with the strain consolidation of the ground $\left(U_{95}=95 \%\right)$ is defined as the standard ground settlement under each load (i.e., $S_{m i}=S_{f i} \cdot U_{95}$ ), and the corresponding standard settlement time $t_{m i}$ can be calculated according to the hyperbolic method.

(4) In the post-preloading period $\left(t_{T i}-t_{m i}\right)$ under each stage loading, the monitoring time interval can be increased to record the pre-preload settlement data $\left(S_{(T+\Delta) i}, t_{(T+\Delta) i}\right),\left(S_{(T+2 \Delta) i}, t_{(T+2 \Delta) i}\right) \cdots\left(S_{m i}^{\prime}, t_{m i}\right)$.

(5) Determine the relationship between the measured settlement $S_{m i}^{\prime}$ for each stage at the standard settlement time and $S_{m i}$. If $S_{m i}^{\prime} \geq S_{m i}$, then the ground meets the requirement of settlement stability.

(6) Check whether the deep lateral displacement rate $\left(B_{i}=\Delta L / \Delta t\right)$ of each stage is less than $5 \mathrm{~mm} / \mathrm{d}$, which is the criterion for stability assessment of safe ground.

The process of conducting the staged construction is shown in Figure 1.

For the marine sedimentary soft soil with high water content, high compressibility, and low permeability, consolidation deformation is a long-term and slow process. A large number of engineering practices have shown that the actual consolidation deformation and stabilization time are larger than those calculated by consolidation theory. In view of this, using 95\% degree of consolidation as the control standard can improve the consolidation deformation of embankment during the construction period, so as to effectively reduce the postconstruction settlement.
For the lateral displacement, the maximum value often occurs in a certain depth of soil layer, which is much larger than the lateral displacement of the surface. The deep lateral displacement can truly reflect the lateral compression effect of soft soil foundation. Therefore, the surface lateral displacement control standard of $5 \mathrm{~mm} / \mathrm{d}$ is still adopted for the deep lateral displacement, which improves the stability control standard and can ensure the stability of the foundation during the filling construction.

\section{Case Study}

4.1. Project Overview. The embankment construction site, which is mainly distributed in the sea tidal flat and local mountain terraces, is located in Fu Jian, China, as shown in Figure 2. The entire embankment located on the deep soft ground with the highest thickness value of $23.5 \mathrm{~m}$ is shown in Figure 3. The silt has high water content, large compressibility, and low penetrability, which can lead to large deformation and differential settlement, as well as long consolidation time. The PVDs combined with staged preloading methods are adopted to improve the soft soil in this case.

4.2. Geological Conditions. In the case study, four sections were included. The $\mathrm{K} 53+787$ construction section with a $23.5 \mathrm{~m}$-thick soft soil layer is the typical section for this study on subgrade consolidation stability control. The soil parameters were obtained through in situ sampling and an indoor test, which are shown in Figure 4. The soil deposit is mainly made of silt and silt clay, with the former being $17 \mathrm{~m}$ and prevailing in the upper part of the deposit and the latter being located at a depth of approximately $z=17-21.2 \mathrm{~m}$; the bottom layer is $2.3 \mathrm{~m}$ of medium sand (Figure 4(a)). The soil deposit belongs to high-compressive soil, and the average compression coefficient $C_{c}$ is 1.1 (Figure $4(\mathrm{~d})$ ). The minimum values of the horizontal permeability coefficient $k_{\mathrm{h}}$ and the vertical permeability coefficient $k_{\mathrm{v}}$ are $1.07 \times 10^{-4} \mathrm{~m} / \mathrm{d}$ and $0.82 \times 10^{-4} \mathrm{~m} / \mathrm{d}$ (Figures $4(\mathrm{e})$ and $4(\mathrm{f})$ ) in the upper $17 \mathrm{~m}$ of the soil deposit, respectively. In addition, the average water content of the silt is $56.3 \%$, which is higher than the liquid limit of $45.9 \%$ (Figure $4(\mathrm{~b})$ ).

4.3. Scheme of Field Monitoring. The arrangement of PVDs and the monitoring sensors in the selected cross-section is depicted in Figure 5. PVDs were arranged in a triangular pattern with a spacing of $1 \mathrm{~m}$ and a depth of $20 \mathrm{~m}$ under the sand mat crossing under the soft soil layer of $1 \mathrm{~m}$.

The field behavior of the soft ground under load filling was observed by monitoring the surface settlement, the Earth pressure, the deep lateral displacement of the subsoil at the embankment side slope foot, the pore pressure variation, and the layered settlement at different depths.

In this study, a settlement profile was laid under the sand mat to monitor the uneven settlement of the subgrade surface. The deep lateral displacement of the subgrade was monitored by inclinometers arranged at the $A$ and $E$ measuring points. The deep soil layered settlements, pore 


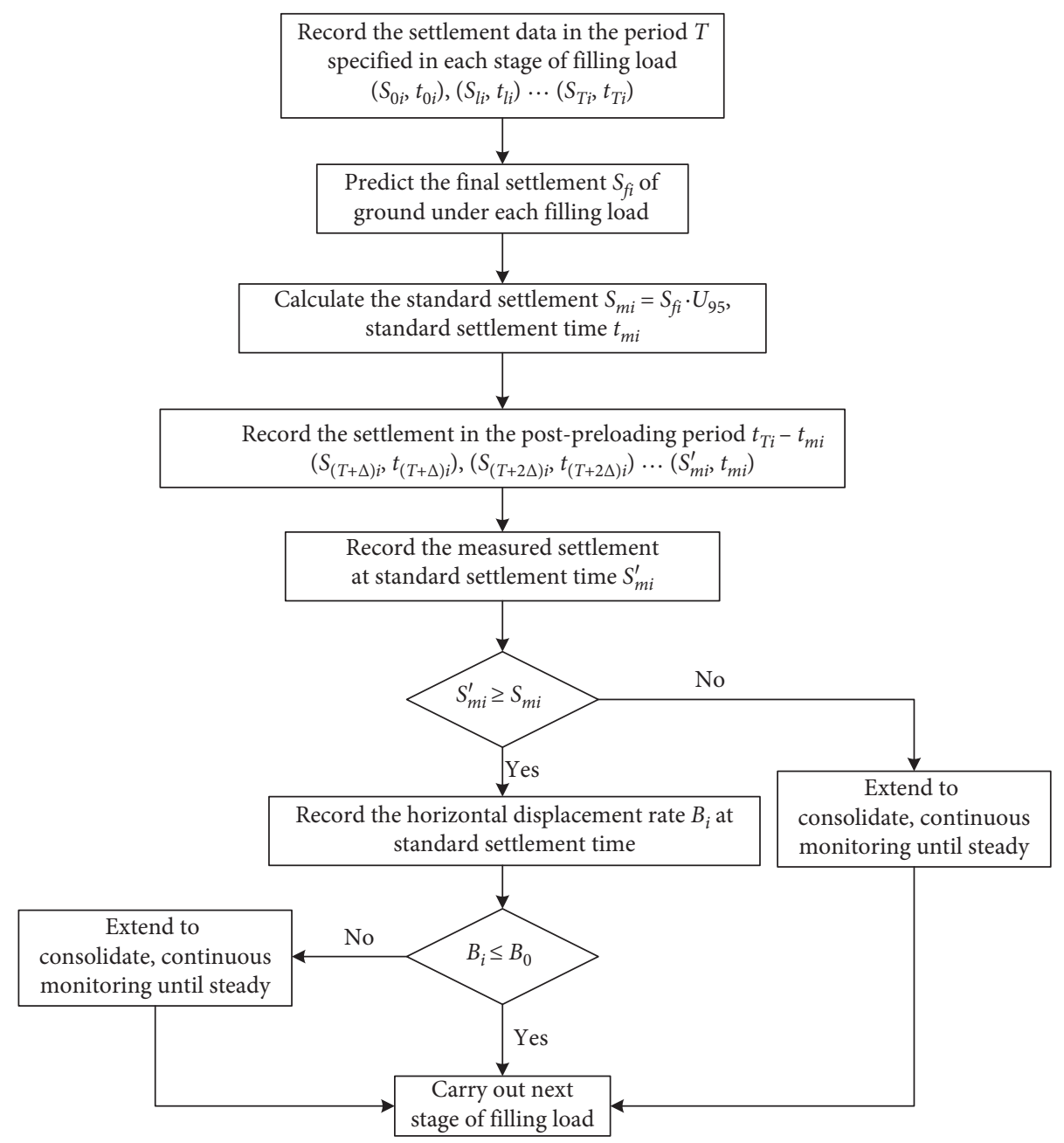

Figure 1: Staged construction conduction flowchart.

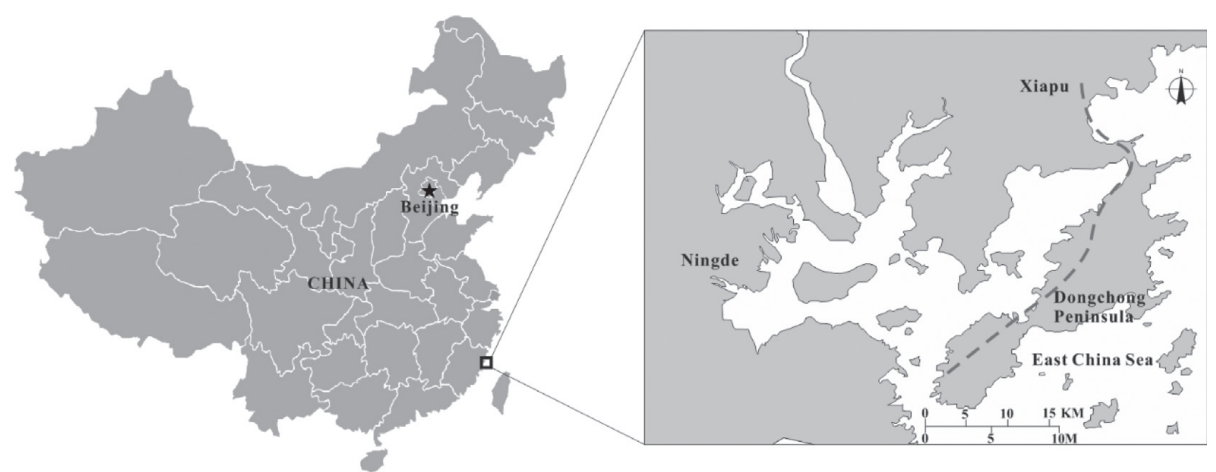

Figure 2: Location of the test site at $\mathrm{Xia} \mathrm{Pu}, \mathrm{Fu}$ Jian, China.

pressure, and Earth pressure were observed by the layered settlement gauges, piezometers, and Earth pressure cells at the $B, C$, and $D$ monitoring points, respectively. Layered settlement gauges and piezometers were installed at different depths of $4 \mathrm{~m}, 7 \mathrm{~m}, 10 \mathrm{~m}, 13 \mathrm{~m}$, and $16 \mathrm{~m}$ from the ground. The Earth pressure cells were arranged under the sand mat. Site data collection is shown in Figure 6. Table 1 presents the field monitoring sensor types and quantity in the $\mathrm{K} 53+787$ construction section.
4.4. Staged Guidance Construction Based on Controlling the Preloading Period. During the embankment construction process, the embankment surface of the uneven settlement data can be obtained based on the settlement profile. From this embankment surface, the settlement data with the monitoring time at the middle point of the embankment would be selected for the final settlement prediction under each load based on the hyperbolic method. The staged guidance construction can be performed by controlling the 


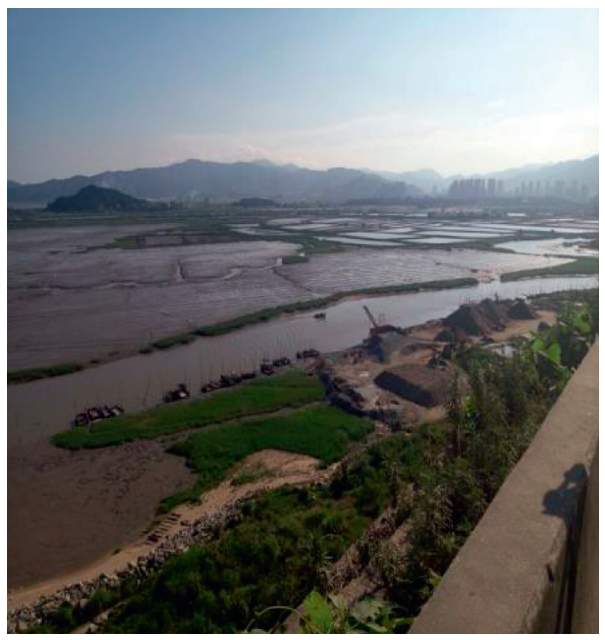

Figure 3: Tidal flat for case study.

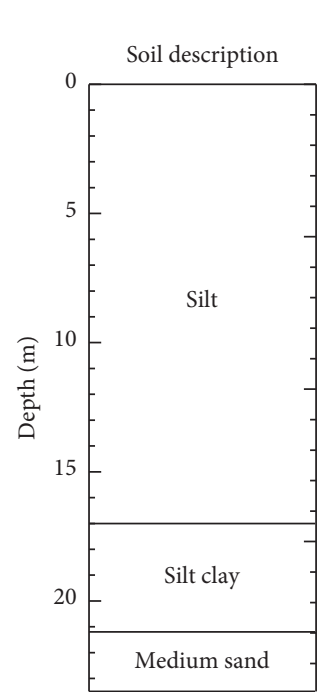

(a)

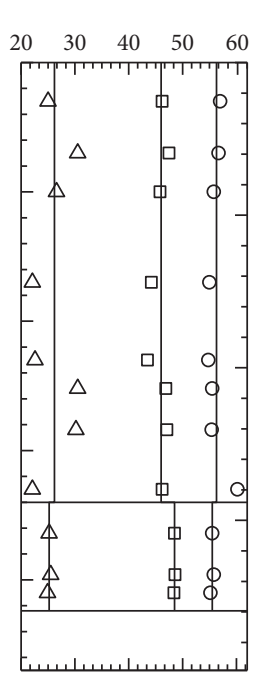

(b)
$\gamma\left(\mathrm{kN} / \mathrm{m}^{3}\right)$

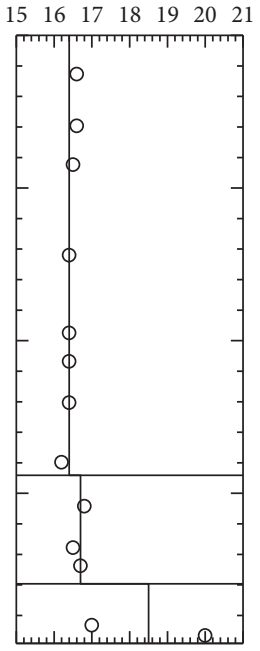

(c)

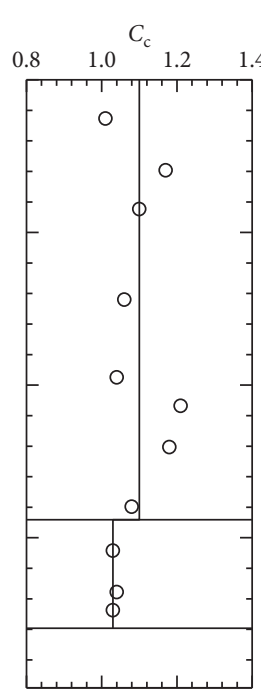

(d) $k_{\mathrm{h}}\left(10^{-5} \mathrm{~m} / \mathrm{d}\right)$

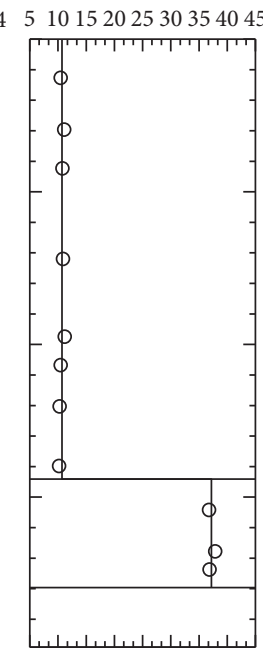

(e) $k_{\mathrm{v}}\left(10^{-5} \mathrm{~m} / \mathrm{d}\right)$

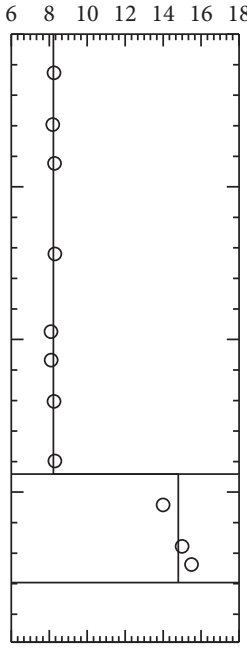

(f)

$$
\begin{aligned}
& \triangle-\mathrm{PL} \\
& \square-\mathrm{LL} \\
& \mathrm{O}-w_{\mathrm{n}}(\%)
\end{aligned}
$$

FIGURE 4: Soil profile and properties of the K53 +787 construction section. Note: PL: plastic limit; LL: liquid limit; $w_{\mathrm{n}}:$ water content; $\gamma:$ unit weight; $C_{\mathrm{c}}$ : compressive coefficient; $k_{\mathrm{h}}, k_{\mathrm{v}}$ : hydraulic conductivity in horizontal and vertical directions, respectively.

predicted preloading period according to the final settlement.

The designed height of embankment is $4.6 \mathrm{~m}$, and actual filling height of surcharge preloading is $6.6 \mathrm{~m}$, which is completed in 5 filling stages.

The thickness $H_{1}$ of the first-grade fill is $0.8 \mathrm{~m}$. The data of the $1 \mathrm{~A}-1 \mathrm{~B}$ section are the settlement monitoring data in the loading stage, and the loading period $t_{11}$ is 3 days, as shown in Figure 7. On the basis of the hyperbolic method, the final settlement of embankment $S_{\mathrm{f} 1}$ under this stage can be predicted according to the settlement monitoring data in the $1 \mathrm{C}-1 \mathrm{D}$ section of the early preloading stage for $T=10$ days. The prediction starting point $t_{01}$ is set at the fourth day, and the initial settlement $S_{01}$ is $136.26 \mathrm{~mm}$. The termination time $t_{T 1}$ for the settlement predicted in this stage is the thirteenth day, and the termination settlement $S_{T 1}$ is $168.72 \mathrm{~mm}$. Figure 8 shows the relationship of $(t-$ $\left.t_{01}\right) /\left(S_{t}-S_{01}\right)$ and $\left(t-t_{01}\right)$ in this stage, in which the settlement data and monitoring time are linearly fitted, correlation coefficient $\rho=0.9908$, and intercept $\alpha$ and slope $\beta$ of the straight line are 0.1102 and 0.018 , respectively. The final predicted settlement $S_{f 1}$ can be obtained as $S_{f 1}=S_{01}+$ $1 / \beta=136.26+1 / 0.018=191.82 \mathrm{~mm}$. The standard settlement can also be obtained as $S_{m 1}=U_{95} \cdot S_{f 1}=0.95 \times$ $191.28=182.22 \mathrm{~mm}$, and the corresponding standard settlement time $t_{m 1}$ is 30 days based on equation (2). The monitoring interval can be increased according to $t_{m 1}$. The data obtained from field monitoring is shown as the $1 \mathrm{E}-1 \mathrm{~F}$ 


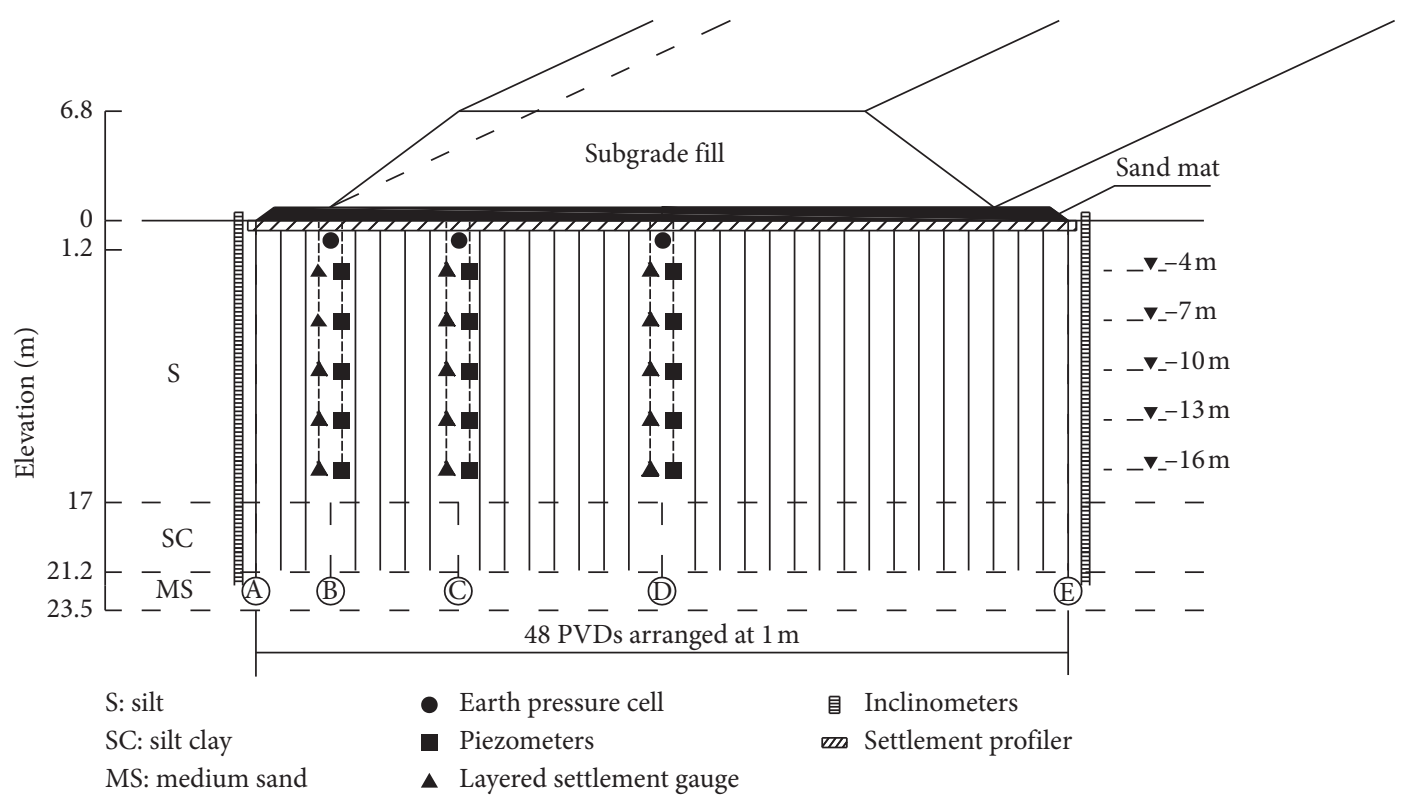

Figure 5: Cross-sectional view of the embankment.

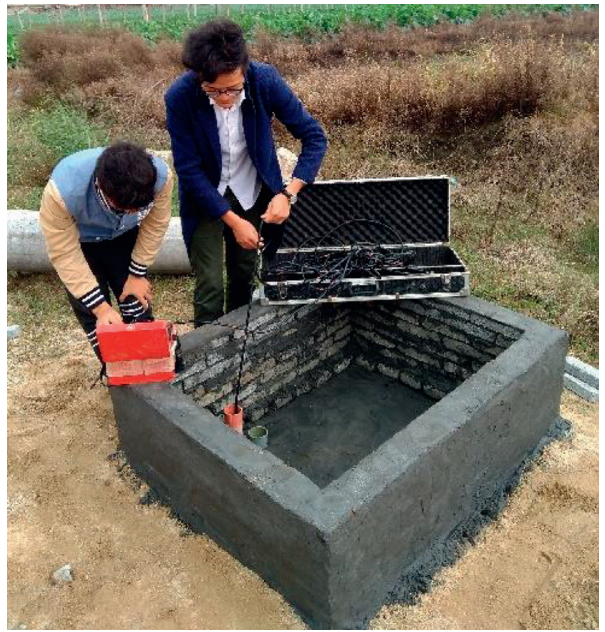

Figure 6: Site data collection.

TABLE 1: Summary of the monitoring sensors in the K53 + 787 construction section.

\begin{tabular}{lccc}
\hline Number & Monitoring project & Sensors & Amount \\
\hline 1 & Uneven surface settlement & Settlement profile & 1 \\
2 & Deep lateral displacement on embankment & Inclinometer & \\
3 & Layered soil settlement & Layered settlement gauge & 15 \\
4 & Pore pressure & Piezometers & 15 \\
5 & Earth pressure & Earth pressure cell & 3 \\
\hline
\end{tabular}

section in Figure 7. The measured standard settlement $S_{m 1}{ }^{\prime}$ is $184.34 \mathrm{~mm}$. Therefore, the subgrade settlement consolidation is basically stabilized under the load filling in the first stage because $S_{m 1}^{\prime}>S_{m 1}$.

The thickness $\mathrm{H}_{2}$ of the second-grade fill is $1.35 \mathrm{~m}$. The loading time $t_{22}$ is 12 days (Figure $9(\mathrm{a})$ ). The final settlement $S_{f 2}$ is $506.42 \mathrm{~mm}$ in the second stage, the standard settlement $S_{m 2}$ is $481.1 \mathrm{~mm}$, and the standard settlement time $t_{m 2}$ is 35 days. The measured standard settlement $S_{m 2}{ }^{\prime}$ is $486.74 \mathrm{~mm}$. Therefore, the subgrade settlement consolidation is basically stabilized under the load filling in the second stage because $S_{2 m}{ }^{\prime}>S_{2 m}$.

The thickness $\mathrm{H}_{3}$ of the third-grade fill is $1.25 \mathrm{~m}$. The loading time $t_{33}$ is 30 days (Figure 9(b)). The final settlement $S_{f 3}$ is $690.82 \mathrm{~mm}$ in the third stage, the standard settlement $S_{m 3}$ is $656.28 \mathrm{~mm}$, and the standard settlement time $t_{m 3}$ is 21 


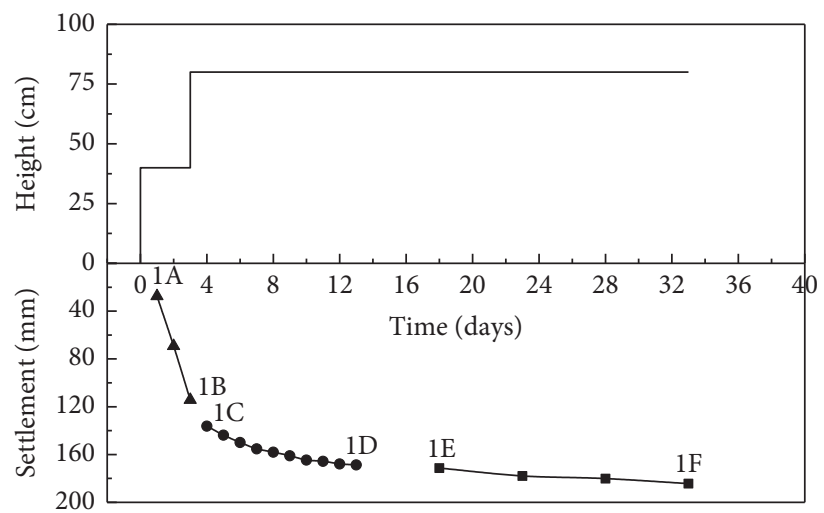

FIgURE 7: Fill height and settlement varying with time in the first stage.

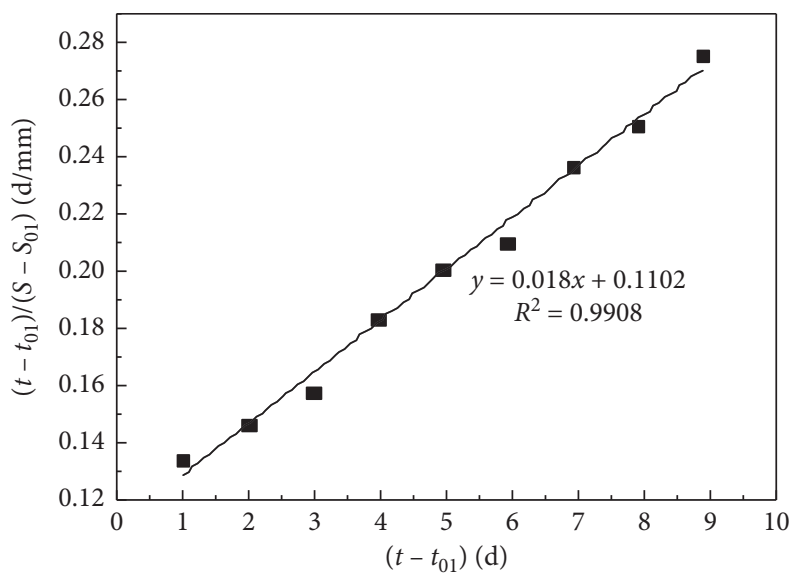

Figure 8: Relationship of $\left(t-t_{01}\right) /\left(S_{t}-S_{01}\right)$ and $\left(t-t_{01}\right)$ in the first stage.

days. The measured standard settlement $S_{m 3}{ }^{\prime}$ is $659.64 \mathrm{~mm}$. Therefore, the subgrade settlement consolidation is basically stabilized under the load filling in the third stage because $S_{m 3}^{\prime}>S_{\mathrm{m} 3}$.

The thickness $\mathrm{H}_{4}$ of the fourth-grade fill is $1.8 \mathrm{~m}$. The loading time $t_{44}$ is 32 days (Figure $9(\mathrm{c})$ ). The final settlement $S_{f 4}$ is $943.11 \mathrm{~mm}$ in the fourth stage, the standard settlement $S_{m 4}$ is $895.95 \mathrm{~mm}$, and the standard settlement time $t_{m 4}$ is 32 days. The measured standard settlement $S_{m 4}{ }^{\prime}$ is $896.15 \mathrm{~mm}$. Therefore, the subgrade settlement consolidation is basically stabilized under the load filling in the fourth stage because $S_{m 4}^{\prime}>S_{\mathrm{m} 4}$.

The thickness $H_{5}$ of the fifth-grade fill is $1.4 \mathrm{~m}$. The loading time $t_{55}$ is 13 days (Figure $9(\mathrm{~d})$ ). The settlement monitoring data of the $5 \mathrm{C}-5 \mathrm{D}$ section are recorded at the earlier period of preloading. The final settlement $S_{f 5}$ is $1077.72 \mathrm{~mm}$ in the fifth stage. The measured subgrade settlement $S_{T 5}$ is $1028.29 \mathrm{~mm}$ at the termination time $t_{T 5}=$ 213rd day at the earlier period of preloading under this load, and the embankment has been basically consolidated at this time. In the latter period of preloading, the monitoring time interval $\Delta=5 \mathrm{~d}$ can be considered first when the settlement is basically stable and the monitoring time interval is $\Delta=15 \mathrm{~d}$. Through the real-time monitoring of the subgrade settlement in the latter part of the preloading period, the embankment can be stabilized until the designed preload period is reached. Then, the construction of the pavement structure can be performed.

As shown in Figure 9, the settlement of each soil layer increases rapidly, and the settlement rate is larger during the loading period. During the intermittent period of filling, settlement development is gradually stabilized and changes, which yields a hyperbolic curve. The entire settlement curve presents a step shape, and the settlement data of each loading-intermittent stage constitute a settlement step.

Table 2 presents the construction time control in each stage. At the end of the control time on the latter period of the preload-bearing compression in each stage, all the consolidation settlements of the ground have reached the requirements of consolidation stability. The final settlement of each stage is predicted using the hyperbolic method. The standard settlement and the standard settlement time of the ground under each stage load are estimated, and the time of stopping-preload is then estimated under the load in all stages. The interval of the site settlement observation time has increased; thus, the efficiency of in situ monitoring can be improved. The construction teams will obtain settlement consolidation stability time in each stage, thereby ensuring that the site construction is in an orderly manner. 


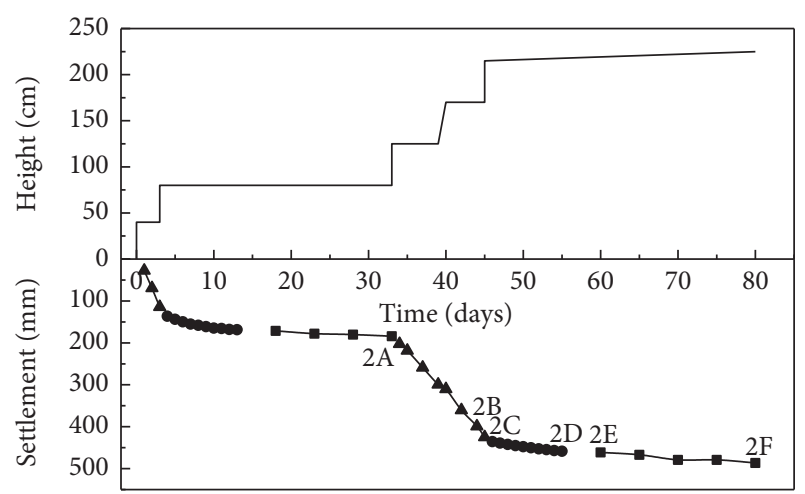

(a)

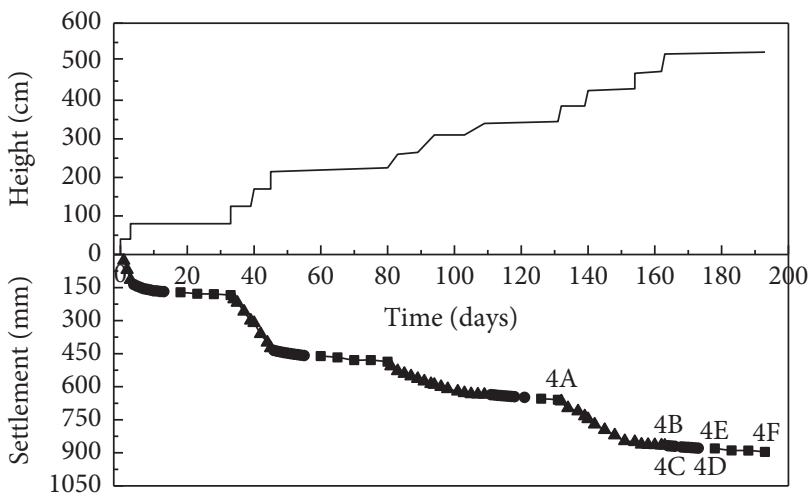

(c)

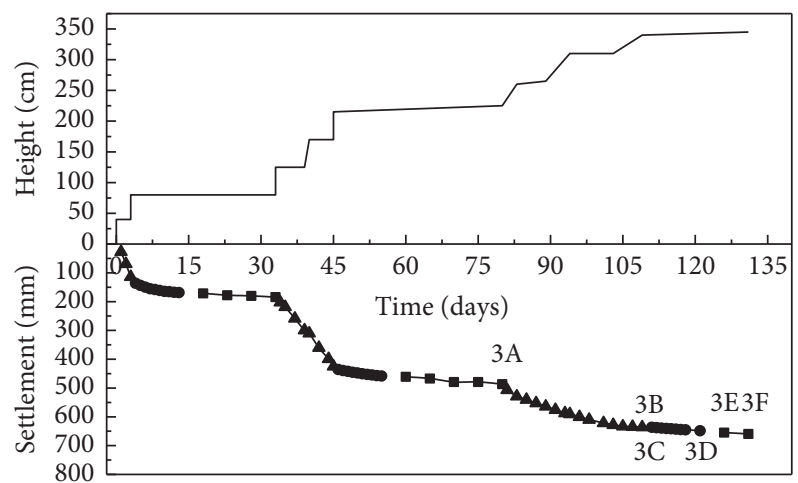

(b)

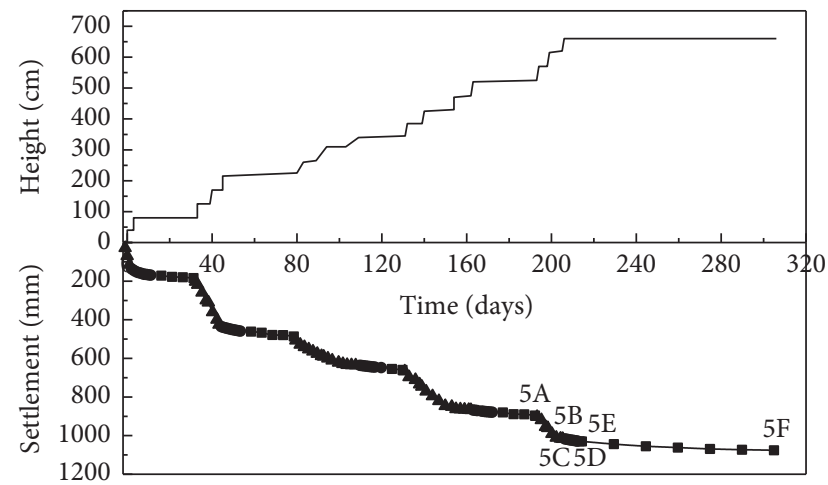

(d)

Figure 9: Fill height and settlement varying with time in all stages. (a) Second stage. (b) Third stage. (c) Fourth stage. (d) Fifth stage.

TABLE 2: Construction period in each stage.

\begin{tabular}{lcccc}
\hline $\begin{array}{l}\text { Load } \\
\text { grade }\end{array}$ & $\begin{array}{c}\text { Filling height } H \\
(\mathrm{~m})\end{array}$ & $\begin{array}{c}\text { Embankment filling period } \\
(\mathrm{d})\end{array}$ & $\begin{array}{c}\text { Earlier period of } \\
\text { preloading }(\mathrm{d})\end{array}$ & $\begin{array}{c}\text { Control time in the latter part of the preloading } \\
\text { period }(\mathrm{d})\end{array}$ \\
\hline I & 0.8 & $1-3$ & $4-13$ & $14-33$ \\
II & 1.35 & $34-45$ & $46-55$ & $56-80$ \\
III & 1.25 & $81-110$ & $111-121$ & $122-131$ \\
IV & 1.8 & $132-163$ & $164-173$ & $174-193$ \\
V & 1.4 & $194-206$ & $207-213$ & $214-306$ \\
\hline
\end{tabular}

4.5. Construction Stability Control Based on the Deep Lateral Displacement Rate of the Foot on the Embankment. Two or more methods should be adopted to control the construction of the site monitoring project. The observation results, which are comprehensively analyzed with various methods, can accurately and objectively evaluate the stability of the embankment. The inclinometer is used to measure the deep lateral displacement of the deep soil. The rate and the value of the deep lateral displacement are the important indexes of the embankment stability. According to the standards, the load capacity and stability control requirements should be satisfied during the loading process. The deep lateral displacement of the foot on the embankment should not exceed $5 \mathrm{~mm} / \mathrm{d}$ [33].

The deep lateral displacement of the deep soil is measured by the inclinometer. The curves of the deep lateral displacement of soil at different depths with time of the foot on the embankment in the preload control period of each stage are shown in Figures $10(\mathrm{a})-10(\mathrm{~d})$. In Figure 10, the deep lateral displacement gradually increases with the loading of the graded fill. Within the depth of the horizontal displacement influence, the maximum displacement occurs at approximately $9.5 \mathrm{~m}$ below the surface, and the position of the maximum deep lateral displacement does not vary with the height and time of the load. The deep lateral displacement on the embankment basically cannot be moved close to the standard settlement time in each stage of the load.

The deep lateral displacement rate $B=\Delta L / \Delta t$ before and after the standard settlement time is recorded in each stage of the load. Table 3 shows the deep lateral displacement rate in the first to the fourth stage. The deep lateral displacement rate of the embankment meets the requirements of the standards. That is, the embankment is achieved in a consolidation stable state in the preloading period of each load. 


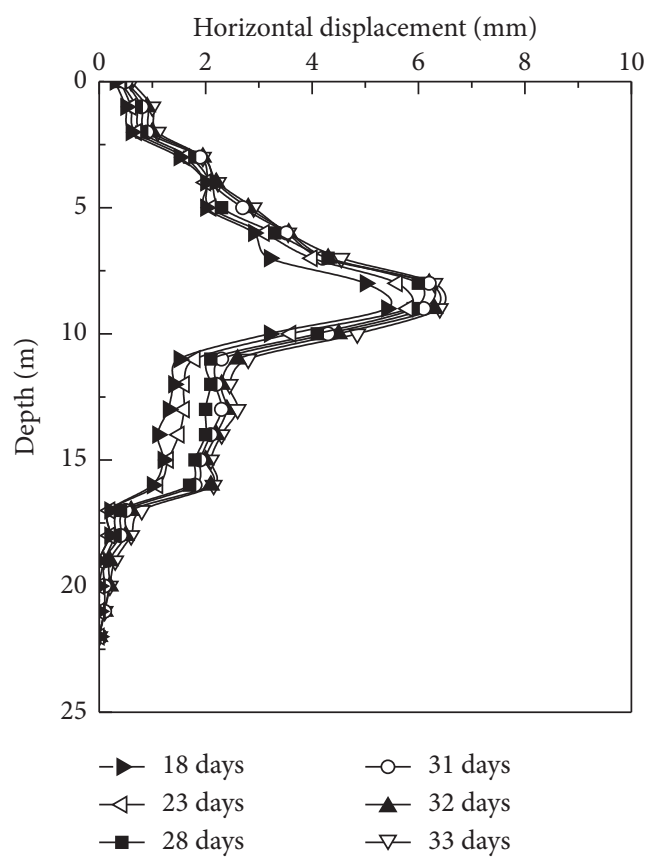

(a)

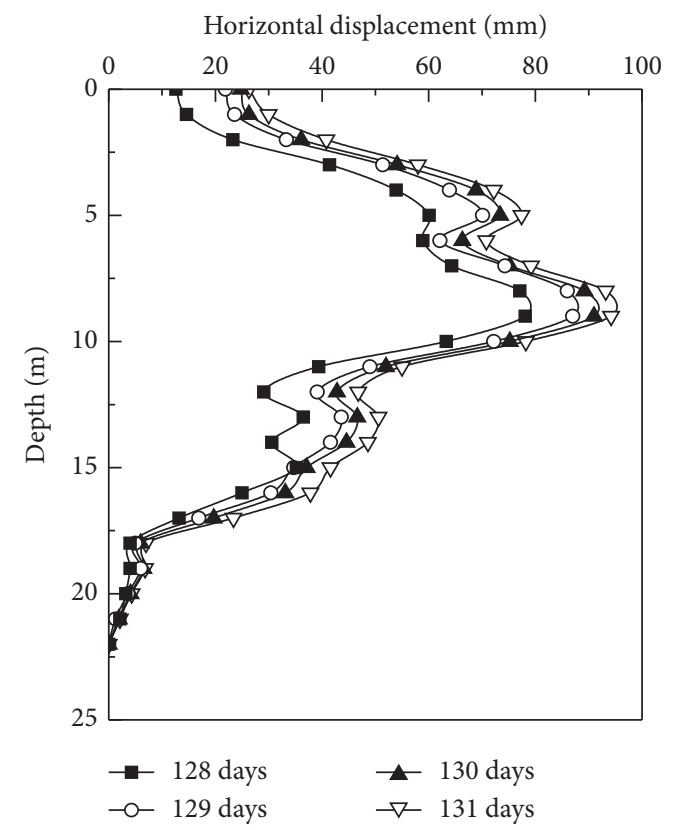

(c)

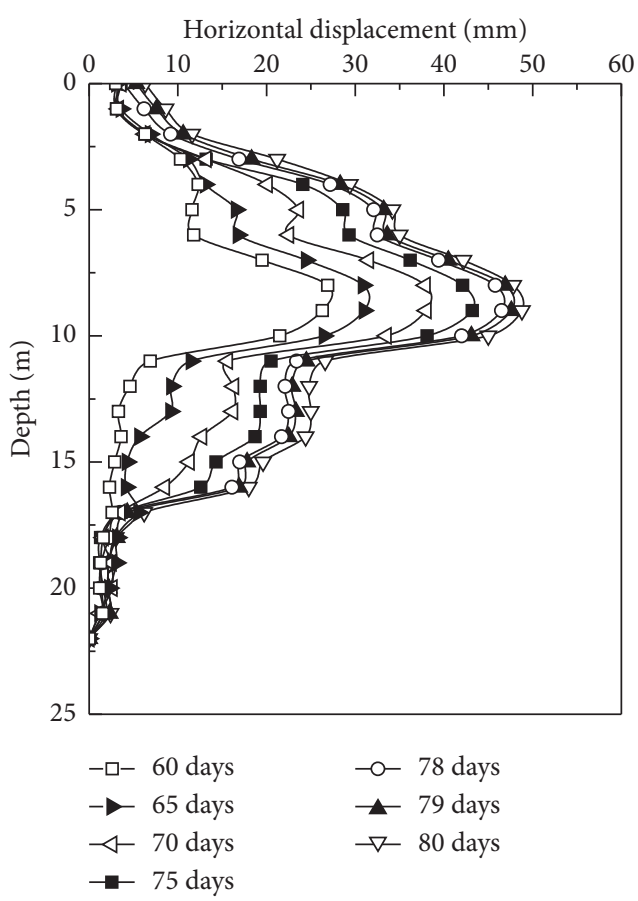

(b)

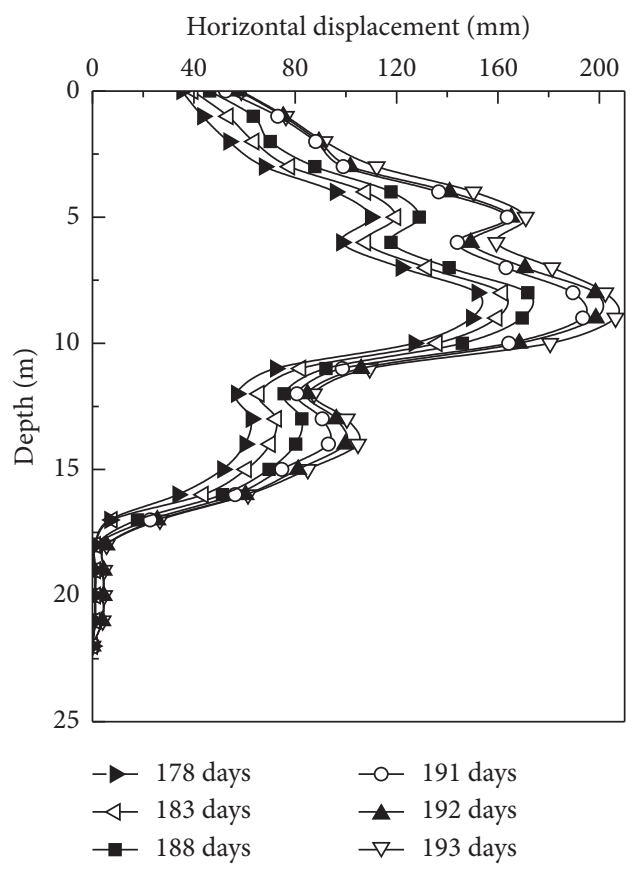

(d)

Figure 10: Deep lateral displacement of soil at different depths with time of the foot on the embankment in all stages.

TABLE 3: Deep lateral displacement rate for the preload control period in each stage.

\begin{tabular}{lccc}
\hline Load level & Horizontal displacement rate $B(\mathrm{~mm} / \mathrm{d})$ & Standard deep lateral displacement rate $B_{0}(\mathrm{~mm} / \mathrm{d})$ & Stable or not \\
\hline I & 0.9 & 5 & Yes \\
II & 1.2 & 5 & Yes \\
III & 3.2 & 5 & Yes \\
IV & 3.8 & 5 & Yes \\
\hline
\end{tabular}




\section{Conclusion}

(1) The analysis of site settlement monitoring data verifies that the standard consolidation time of the ground is obtained under each stage loading to guide the construction according to the preloading period estimated under each loading stage. Therefore, the interval of the site settlement observation time has increased, the efficiency of in situ monitoring can be improved, and the site construction can be ensured in an orderly manner.

(2) By observing the embankment settlement and deep lateral displacement, the filling construction stage can be comprehensively and systematically controlled in real time, which can solve the problem that traditional consolidation theory cannot consider the large randomness of the loading and soil parameters of the spatial variability and other issues during the process of embankment filling.

(3) In this study, the proposed engineering case confirms that the deep lateral displacement rate at the ground standard settlement time estimated by the site settlement monitoring data of the foot on the embankment can meet the requirements of the stability of the standards based on the hyperbolic method. Thus, the stability of the ground under the load of each stage is ensured in the embankment filling construction stage on the soft soil.

\section{Data Availability}

No data were used to support this study.

\section{Conflicts of Interest}

The authors declare that they have no conflicts of interest.

\section{Acknowledgments}

This study was funded by the National Natural Science Foundation of China (41702337).

\section{References}

[1] D. T. Bergado, A. S. Balasubramaniam, R. J. Fannin, and R. D. Holtz, "Prefabricated vertical drains (PVDs) in soft Bangkok clay: a case study of the new Bangkok International Airport project," Canadian Geotechnical Journal, vol. 39, no. 2, pp. 304-315, 2002.

[2] J. Chu, M. Bo, and V. Choa, "Improvement of ultra-soft soil using prefabricated vertical drains," Geotextiles and Geomembranes, vol. 24, no. 6, pp. 339-348, 2006.

[3] A. K. Sinha, V. G. Havanagi, and S. Mathur, "An approach to shorten the construction period of high embankment on soft soil improved with PVD," Geotextiles and Geomembranes, vol. 27, no. 6, pp. 488-492, 2009.

[4] Y. Miao, Y. Shi, H. Y. Zhuang, S. Y. Wang, H. B. Liu, and X. B. Yu, "Influence of seasonal frozen soil on near-surface shear wave velocity in eastern hokkaido, Japan," Geophysical Research Letters, vol. 46, no. 16, pp. 9497-9508, 2019.
[5] S. Shen, J. Chai, Z. Hong, and F. Cai, "Analysis of field performance of embankments on soft clay deposit with and without PVD-improvement," Geotextiles and Geomembranes, vol. 23, no. 6, pp. 463-485, 2005.

[6] F. Tavenas and S. Leroueil, "The behaviour of embankments on clay foundations," Canadian Geotechnical Journal, vol. 17, no. 2, pp. 236-260, 1980.

[7] R. A. Barron, "Closure of "consolidation of fine-grained soils by drain wells" Transactions of the American Society of Civil Engineers, vol. 113, no. 6, pp. 751-754, 1948.

[8] L. Kok, M. Jamiolkowski, and S. Hansbo, "Consolidation by vertical drains,” Géotechnique, vol. 31, no. 31, pp. 45-66, 1981.

[9] Q. Zheng, A. C. F. Chiu, G. H. Lei et al., "An analytical solution for consolidation with vertical drains under multiramp loading," Géotechnique, vol. 65, no. 7, pp. 531-547, 2015.

[10] C. Kelln, J. Sharma, D. Hughes, and J. Graham, "Finite element analysis of an embankment on a soft estuarine deposit using an elastic-viscoplastic soil model," Canadian Geotechnical Journal, vol. 46, no. 3, pp. 357-368, 2009.

[11] A. Arulrajah, H. Nikraz, and M. W. Bo, "Observational method of assessing improvement of marine clay," Proceedings of the Institution of Civil Engineers - Ground Improvement, vol. 8, no. 4, pp. 151-169, 2004.

[12] G. D. Filippo, V. Bandini, E. Cascone et al., "Measurements and predictions of settlements induced by preloading and vertical drains on a heterogeneous soil deposit," Measurement, vol. 104, pp. 302-315, 2016.

[13] R. Chen, D. Li, and Y. Xu, "Analysis and improvement of fitting models for predicting subsidence under high-speed railway lines," Geotechnical and Geological Engineering, vol. 34, no. 1, pp. 29-35, 2016.

[14] A. K. Sinha, V. G. Havanagi, and S. Mathur, "Inflection point method for predicting settlement of PVD improved soft clay under embankments," Geotextiles and Geomembranes, vol. 25, no. 6, pp. 336-345, 2007.

[15] S. M. Haeri and M. Sasar, "Improving final settlement predictions of the observational method," Proceedings of the Institution of Civil Engineers-Geotechnical Engineering, vol. 166, no. 6, pp. 601-609, 2013.

[16] X. Wang, X. Zhang, and X. Wu, "Observational settlement prediction of composite foundation in east artificial island by two curve fitting methods," Electronic Journal of Geotechnical Engineering, vol. 21, no. 18, pp. 5907-5917, 2016.

[17] A. Sridharan, N. S. Murthy, and K. Prakash, "Rectangular hyperbola method of consolidation analysis," Géotechnique, vol. 37, no. 3, pp. 355-368, 1987.

[18] S.-A. Tan, "Validation of hyperbolic method for settlement in clays with vertical drains," Soils and Foundations, vol. 35, no. 1, pp. 101-113, 1995.

[19] S.-A. Tan and S.-H. Chew, "Comparison of the hyperbolic and Asaoka observational method of monitoring consolidation with vertical drains," Soils and Foundations, vol. 36, no. 3, pp. 31-42, 1996.

[20] Y. Miao, E. Yao, B. Ruan, H. Zhuang, G. Chen, and X. Long, "Improved hilbert spectral representation method and its application to seismic analysis of shield tunnel subjected to spatially correlated ground motions," Soil Dynamics and Earthquake Engineering, vol. 111, pp. 119-130, 2018.

[21] C. Li, "A simplified method for prediction of embankment settlement in clays," Journal of Rock Mechanics and Geotechnical Engineering, vol. 6, no. 1, pp. 61-66, 2014.

[22] A. Arulrajah, H. Nikraz, and M. W. Bo, "Factors affecting field instrumentation assessment of marine clay treated with 
prefabricated vertical drains," Geotextiles and Geomembranes, vol. 22, no. 5, pp. 415-437, 2004.

[23] B. Indraratna and I. W. Redana, "Numerical modeling of vertical drains with smear and well resistance installed in soft clay," Canadian Geotechnical Journal, vol. 37, no. 1, pp. 132-145, 2000.

[24] D. G. Lin and K. T. Chang, "Three-dimensional numerical modelling of soft ground improved by prefabricated vertical drains," Geosynthetics International, vol. 16, no. 5, pp. 339-353, 2009.

[25] J.-H. Kim, S.-H. Kang, and T.-H. Kim, "Settlement prediction for staged filling construction on the PVD-improved soft ground using SPSFC method," Procedia Earth and Planetary Science, vol. 15, pp. 146-151, 2015.

[26] Y. Miao, E. Yao, B. Ruan, and H. Zhuang, "Seismic response of shield tunnel subjected to spatially varying earthquake ground motions," Tunnelling and Underground Space Technology, vol. 77, pp. 216-226, 2018.

[27] T. Yang, "Settlement prediction of stage-constructed embankment on soft ground using the exponent fitting method," China Civil Engineering Journal, vol. 38, no. 5, pp. 92-95, 2005, in Chinese.

[28] L. Ma, S. L. Shen, and X. W. Tang, "Strength increase of PVDimproved soft clay under staged embankment loading," Geosynthetics in Civil and Environmental Engineering, pp. 456-459, 2008.

[29] S. Leroueil, J. P. Magnan, and F. Tavenas, Embankments on Soft Clays, Ellis Horwood Ltd., Lichfield, UK, 1990.

[30] T. Yang, G. W. Li, and W. Q. Yang, "Settlement prediction of stage constructed embankment on soft ground based on the hyperbolic method," Rock and Soil Mechanics, vol. 25, no. 10, pp. 1551-1554, 2004, in Chinese.

[31] S. Y. Liu and F. Jing, "Settlement prediction of embankments with stage construction on soft ground," Chinese Journal of Geotechnical Engineering, vol. 25, no. 2, pp. 228-232, 2003.

[32] T. S. Tan, T. Inoue, and S. L. Lee, "Hyperbolic method for consolidation analysis," Journal of Geotechnical Engineering, vol. 117, no. 11, pp. 1723-1737, 1991.

[33] National Standard of China, People's Republic of China Ministry of Housing and Urban and Rural Development Issued by the People's Republic of China Industry Standards. Building Foundation Treatment Technical Specifications, China Construction Industry Press, Beijing, China, 2013, in Chinese. 